\title{
Women's adversities
}

\author{
Adversidades no feminino \\ Adversidades en las mujeres
}

Received: 10/28/2021 | Reviewed: 11/07/2021 | Accept: 11/15/2021| Published: 12/05/2021

\author{
Ana Paula Guimarães \\ ORCID: https://orcid.org/0000-0002-0813-4789 \\ Portucalense University, Portugal \\ E-mail: apg@upt.pt \\ Maria Manuela Magalhães Silva \\ ORCID: https://orcid.org/0000-0003-4261-7271 \\ Portucalense University, Portugal \\ E-mail: mmdmms@uportu.pt \\ Fernanda Rebelo \\ ORCID: https://orcid.org/0000-0002-4598-1629 \\ Portucalense University, Portugal \\ E-mail: fmnr@upt.pt
}

\begin{abstract}
It is up to the State to promote appropriate measures to "guarantee fundamental rights and freedoms and the respect for the principles of a democratic law State", in accordance with Article 9 (b) of the Constitution of the Portuguese Republic. Our objectives were to examine how the Portuguese legislator is attentive to the particularities of being a woman in matters such as hygiene, health, motherhood and parental education during the execution of sentences and we wanted to investigate the mechanisms triggered by the State for protection, as a preventive measure, of women as victims of crimes. We made research, in numerical terms, to know the rate of constituted women accused in criminal proceedings, as well as the number of convicted, from a set of recent and of reference official documentary sources, based on the existing statistical resources. We also made an analysis of the pertinent legislative diplomas, among them, the aforementioned Code of the Execution of Penalties and Freedom Deprivation Measures and the General Regulation of Prison Establishments. The fulfilment of a prison sentence implies vast and varied consequences, from personal to familiar, passing through social and professional consequences, among others. We concluded that compared to the male universe, the number of women accused and convicted is clearly lower. On the other hand, it is women who make up the largest share as victims of certain offenses. According to the 2019 Annual Report, authored by APAV, female victims amounted to 8,394.
\end{abstract}

Keywords: Women; Adversities; Freedom deprivation; Execution of sentences; Victim.

\section{Resumo}

Cabe ao Estado promover as diligências adequadas a "garantir os direitos e liberdades fundamentais e o respeito pelos princípios do Estado de direito democrático", em conformidade com a alínea b) do artigo $9 .^{\circ}$ da Constituição da República Portuguesa. Pretendemos examinar como o legislador português teve em conta as particularidades de ser mulher em questões como a higiene, a saúde, a maternidade e a educação parental na fase da execução das penas e pesquisámos os mecanismos estaduais para a proteção, a título preventivo, das mulheres enquanto vítimas de crimes. Fizemos um levantamento numérico, indagando a taxa de mulheres constituídas arguidas em processos-crime, bem como o número de condenadas, a partir de um conjunto de recentes fontes documentais de referência e oficiais, com base nos recursos estatísticos existentes. Fizemos também uma incursão pelos diplomas legislativos pertinentes, entre eles, o Código da Execução das Penas e Medidas Privativas da Liberdade e o Regulamento Geral dos Estabelecimentos Prisionais. O cumprimento de uma pena de prisão importa vastas e variadas consequências, desde as pessoais, às familiares, passando pelas sociais e profissionais, entre outras. Concluímos que, em comparação com o universo masculino, o número de mulheres constituídas arguidas e condenadas é claramente inferior. Por outro lado, são as mulheres que constituem a maior parcela enquanto vítimas de determinadas infrações. Segundo Relatório Anual de 2019, de autoria da APAV (Associação Portuguesa de Apoio à Vítima), as vítimas no feminino ascenderam a 8.394 .

Palavras-chave: Mulheres; Adversidades; Privação da liberdade; Execução das penas; Vítima.

\section{Resumen}

Corresponde al Estado promover las medidas adecuadas para "garantizar los derechos y libertades fundamentales y el respeto de los principios del Estado democrático de derecho", de conformidad con el artículo 9 (b) de la Constitución de la República Portuguesa. Nuestros objetivos fueron examinar cómo la legisladora portuguesa tuvo en cuenta las particularidades de ser mujer en temas como higiene, salud, maternidad y educación de los padres durante la ejecución 
de las penas y, además, investigamos los mecanismos de protección que dispara el Estado, como medida preventiva, de las mujeres como víctimas de delitos. Realizamos una encuesta, en términos numéricos, indagando la tasa de mujeres constituidas imputadas en procesos penales, así como el número de condenadas, a partir de un conjunto de referencias recientes y fuentes documentales oficiales, en base a los recursos estadísticos existentes. También hicimos una incursión en los diplomas legislativos pertinentes, entre ellos, el citado Código de Ejecución de Penas y Medidas de Privación Penitenciaria y el Reglamento General de Instalaciones Penitenciarias. El cumplimiento de una pena de prisión conlleva vastas y variadas consecuencias, desde consecuencias personales, familiares, sociales y profesionales, entre otras. Concluimos que, en comparación con el universo masculino, el número de mujeres constituidas acusadas y condenadas es claramente menor. Por otro lado, son las mujeres las que constituyen la mayor proporción de víctimas de determinados delitos. Según el Informe Anual de 2019, elaborado por APAV (Asociación Portuguesa de Apoyo a las Víctimas), las víctimas femeninas ascendieron a 8.394.

Palabras clave: Mujeres; Adversidades; Privación de libertad; Ejecución de sentencias; Víctima.

\section{Introduction}

The fulfilment of a prison sentence implies vast and varied consequences, from personal to familiar, passing through social and professional consequences, among others. And when women are condemned, the enforcement of sanctions has its singularities, namely, pregnancy and the postpartum situations. Compared to the male universe, the number of women accused and convicted is clearly lower. On the other hand, it is women who make up the largest share as victims of certain offenses, as is the case with domestic violence. In this sense, some figures on female reclusion reveal the situation in Portugal. In 2019, there were 859 Portuguese female inmates in Portuguese prisons, clearly less than 11,948 male inmates, according to statistics from the Directorate-General for Justice Policy (2020) and data provided by Pordata (2020), in a total of 12,793 inmates, having, in the year 2000, the largest number of national women arrested - 1,206. Given the low percentage of female prisoners compared to male prisoners, Cunha (2007) says that: "their specific needs tend to remain in the background of penitentiary policies". This numerical difference in terms of incarceration has been explained by means of arguments that contemplate the type of education that prints a model of differentiated roles to be played in society by men and women, especially in the most disadvantaged environments (Torres \& Gomes, 2002). Beleza (2004) expands the explanation, among other invocations, to the "important role that the processes of criminalization and victimization have in strengthening or defining gender relations".

\section{Methodology}

The methodology used in this research was based on both quantitative and qualitative research methods. The choice between the qualitative, quantitative or mixed methods depends on "which is most appropriate and likely to provide the type of data that will answer the research question (Ary et. al., 2014); these authors "discuss the way in which research is conducted in an attempt to provide answers to important questions". Also, the study of Leitch and Day (2000) focuses on reflective practice and action research. In this research, both methods proved necessary to achieve the results and reach conclusions.

In the quantitative research method, data were quantified in percentage terms (Estrela, 2018, Pereira et al. 2018). We made research, in numerical terms, to know the rate of constituted women accused in criminal proceedings, as well as the number of convicted, from a set of recent and of reference official documentary sources, based on the existing statistical resources. Subsequently, the data was organized and analysed through the action-research method (Lemos, 2012). Using various reports, indicators and statistics, as well as relevant national and European databases, it was possible to obtain meaningful data that cause concern and impel us to act. It is a certain predominant type of criminality that leads women to be deprived of their liberty, which naturally has its importance and significance. On the other hand, it is women who constitute the largest share as victims of certain offences.

The qualitative method, in turn, proved equally appropriate given the objectives to be pursued. It was based on a specialised doctrinal bibliographic analysis, as well as an incursion through the pertinent diplomas of the subject under study, 
among them, the Code of Execution of Penalties and Measures Depriving Freedom and the General Regulation of Prison Establishments. We have examined in what terms the Portuguese legislator takes into account the particularities of the female condition in matters such as hygiene, health, maternity and parental education during the enforcement of sentences. We have tried to ascertain whether, and to what extent, the mechanisms put in place by the State for the preventive protection of women as victims of crime are effective, with the emphasis on the adversities they still face two decades into the 21 st century.

\section{Results}

Of the Portuguese prisoners, until December 31, 2019, three of them were between 16 and 18 years old, 61 between 19 and 24 years old, in the age group between 25 and 39, were 359 women. Between the ages of 40 and 59, there were 373 inmates and aged 60 or over, 63 inmates, according to the Annual Internal Security Report (2019). As for the inmates of foreign nationality, in the total of 201, the division by age is correspondingly 3, 46, 101, 45 and 6 women. The dominant types of crimes are offenses against legal assets such as property, against people and drug traffic crimes. With regard to drug trafficking, the study of Torres \& Gomes (2005) reveals that women are arrested mainly for drug trafficking offences, sentenced to high sentences, while men are convicted more of criminal offences committed associated with drug use.

Without knowing how to read or write, there were 60 women in total, 53 of whom were Portuguese and 7 were foreign. Regarding the level of education, the number of women with basic education up to the 4th year dominates - 168 Portuguese inmates.

According to the Directorate-General of Reintegration and Prison Services/Statistics and Indicators/Prisons (2019), as for foreign prisoners, secondary education prevails, between the 10th and 12th years, with a total of 71 prisoners; with higher education there were 31 Portuguese and 23 foreign.

According to official data from the Directorate-General of Reintegration and Prison Services/Statistics and Indicators/Prisons (2019), with regard to capacity, until December 31, 2019, the female section of Funchal housed 299 inmates, below the capacity of 349, Angra do Heroísmo, 269 inmates for 350 places, while Guarda had 257 inmates for a capacity of 264. In Tires, for a capacity of 470 there were 421 inmates. In Santa Cruz do Bispo Feminino there were also 299 inmates with a capacity of 352 . Therefore, it is concluded in the abovementioned document that: there is no overcrowding in these prisons; while serving the sentence, until December 31, 2019, 2 Portuguese prisoners died due to natural causes of illness, no suicides have been registered; whereas as for male prisoners, there were 11 suicides.

\section{Discussion}

\subsection{Some specific needs of women in terms of compliance with a prison sentence}

The Code for the Execution of Penalties and Private Prison Measures, approved by Law No. 115/2009, of 12 October, dictates "respect for the dignity of the human person and the other fundamental principles enshrined in the Constitution of the Portuguese Republic (article 3, paragraph 1). This fundamental decree, in turn, in its article 30, paragraph 5, establishes the prohibition of those convicted of a penalty or security measure depriving their freedom of their fundamental rights, with the obvious exception of limitations and requirements of the respective execution order.

When the sentence is imposed on a woman, the law provides that the enforcement of sanctions takes into account "her specific needs, namely in terms of health, hygiene, maternity protection and parental education" (article 4, paragraph 3) of Law no. 115/2009) and, in terms of structure, the prison system must be organized for the execution of sentences and deprivation of liberty applied to women (article 9 (2) (d)) of mentioned Law).

The article 68 of the Constitution of the Portuguese Republic prescribes: 
"1. Fathers and mothers have the right to the protection of society and the State in carrying out their irreplaceable action in relation to their children, namely regarding their education, with a guarantee of professional fulfilment and participation in the country's civic life. 2. Motherhood and paternity are eminent social values. 3 . Women are entitled to special protection during pregnancy and after childbirth, with working women still being entitled to an exemption from work for an appropriate period, without loss of remuneration or any benefits. 4 . The law regulates the allocation to mothers and fathers of rights to leave work for an appropriate period, according to the interests of the child and the needs of the household".

It also provides for, the article 69 of the Constitution of the Portuguese Republic:

"1. Children have the right to the protection of society and the State, with a view to their integral development, especially against all forms of abandonment, discrimination and oppression and against the abusive exercise of authority in the family and other institutions. 2. The State provides special protection for orphaned, abandoned or otherwise deprived children of a normal family environment".

These are eminently social rights, the first being "protection of fathers and mothers in their rights and duties in relation to their children" and the second "children's right to protection" (Canotilho \& Moreira, 2007). In particular, the issue of motherhood and parental education is quite important in the prison context. Motherhood and the education of minor children is, above all, one of the woman's responsibilities and essentially a commitment to the children, while guaranteeing their wellbeing. Responsibility and commitment whose realization inevitably depends on a wide range of endogenous and exogenous factors. The stereotyped view of and abroad gives women the role of guaranteeing the good functioning of the family, including the education, monitoring and treatment of children. But, more than the assumption of the traditional role attributed to women in the family context, here, it is a matter of providing the child with adequate care with his mother, for the sake of his regular physical and psychological development, as adapted as possible, due to the prison reality. As Matos (2006) noticed, "Regardless of whether they assume different contours in also different historical-cultural contexts, motherhood and conjugality have been identified as essential roles of the ideal of femininity".

\subsubsection{Pregnancy}

Pregnancy, as a rule, constitutes a reason for the woman's personal satisfaction and the materialization of a life project that "within walls" does not bode well for. The pregnant woman's worries intensify family support and monitoring shrink, affective needs increases, sensitivity and emotions increase, fears redouble, and uncertainty about the newcomer expands. Surely, these women will live, at all times, antagonistic feelings, sometimes of happiness, or unhappiness, now of satisfaction, then frustration. Loneliness and social isolation have well-known consequences for well-being and mental health. All considered, it allows us to say that the prison environment is neither the ideal nor the most appropriate for a child's pregnancy phase.

In the context of providing health care to the prisoner, the Penalty Enforcement Code provides that the pregnant woman is authorized to give birth in a hospital (article 34, paragraph 2). In turn, paragraphs 2 and 3 of article 239 of the General Regulation of Prison Establishments (GRPE), DL no. 51/2011, of 11 April, provide that they will be provided with specialized medical assistance during pregnancy or in puerperium and appropriate steps are taken to ensure that childbirth takes place in a non-prison hospital. The transportation of prisoners is guaranteed with due care, and whenever necessary and with the authorization of the director of the prison establishment, using an ambulance (article 240, paragraph 2 of the GRPE).

\subsubsection{Minor Children}

Another face of women's reclusion is maternity experienced within walls. With minor children present in prison or with minor children absent. The deprivation of the detainee's freedom irreparably affects the nuclear family, one of the most 
basic pillars of the emotional balance of each and every person. The family is fragmented. The family also bears the consequences of the prisoner's deprivation of freedom. In legal terms, prisoners can keep their minor children, up to 3 years old or, exceptionally, up to 5 years, with them in the prison. It is a right granted to them in accordance with article 7, paragraph 1, point g), of Law No. 115/2009, with the need for authorization from the other holder of parental responsibility. This way, it is intended that the mother assumes the role of caregiver, that interaction between mother and child is provided and bonds of affection are created. But this solution can take place "by choice or because they have no other alternative" (Guimarães, 2015).

Therefore, it is essential that this solution be in the interest of the minor and that the prison establishment has the necessary conditions. So that, in order to accommodate mother and child, the prison establishment must have a space for accommodation in a separate area from the other prisoners, in its own wing, with furniture and with the appropriate dimensions for the maintenance of the child (article 244 of the GRPE), the inmate being allowed to have in this space the indispensable childcare and hygiene products, clothes and toys, as determined by the director as to their nature and quantities (article 245 of the GRPE).

In case of need to be transported, the inmate has the right to be accompanied by her child if she is breastfeeding (article 240, paragraph 3 of the GRPR). Except for reasons of order or safety, the transportation of inmates accompanied by a minor should preferably be carried out in a non-cellular vehicle (article 248 of the GRPE), preventing stigma.

The inmate placed in a safe regime is prevented from keeping her minor child with her (article 243, paragraph 2 of the GRPE). In case the prisoner enters a disciplinary cell, she must remain in the disciplinary cell between the period of general opening and general closing, being able to accompany the child only during the night, returning to her accommodation space (article 174, no. 9 of GRPE).

The basic need for children's food is guaranteed in the General Regulation, namely, goods such as paediatric milk and porridge, according to medical indications, when the prisoners are proven not to have the means to purchase them. The inmate's meals with the minor child are taken in a separate place from the rest. They are also guaranteed the supply of childcare and childcare products whenever they are proven not to have the means to acquire them (article 246 of the GRPE).

In accordance with article 247 of the General Regulation, medical assistance is provided to minor children in a system of articulation with the National Health Service, and the national vaccination and child health plan is implemented. The other screenings are carried out for the diagnosis and / or treatment of diseases, aiming at "their normal physical and intellectual development". Whenever minors need to leave the prison for an appointment or other medical procedure abroad, they can be accompanied by the parent, according to the director's prior authorization (article 247 of the GRPE).

Playful and age-appropriate leisure activities are provided to minors, either on their own premises or abroad (playgrounds, amusements, games, trips to the beach). Once the prisoner's authorization has been obtained, the prison establishment should, whenever possible, develop the participation of minors abroad in order to guarantee access to public preschool (article 249 of the GRPE), which is of the utmost importance for the socialization "off-walls" children and increase inclusive education.

The III Report of the Ombudsman commends the improvement of the quality of accommodation for women and children in the Portuguese prison system, although it is not perfect (Ombudsman's Office, 2003). With a view to preserving family and emotional ties, maintaining contacts with the outside world and overcoming absence, prisoners who do not keep their children with them can receive visits from children under 16 or maintain contacts with them through the videoconference of the prison establishment, as long as duly authorized by the director (article 58 of Law no. 115/2009). The creation of specific spaces for family gatherings is foreseen, within the scope of the so-called extended family visits, equipped with furniture and other appropriate equipment to stimulate the interaction between the prisoner and minors or between the prisoner, her husband or person with whom have similar relationship and the respective minor descendants (article 112 of GRPE). The 
separation of the prisoner from her children is undoubtedly a cause of pain, anxiety, tension and increased concern. The gender problem is very accentuated in the prison, where it is common to say that while men enter the prison alone, women are burdened with their problems of home, children, family, neighbourhood and work, when they had it. In the words of Matos (2006), "interruption (...) highly disturbing to the woman".

Here comes the end of the penalties, both for general and special prevention. With regard to special prevention aiming at the reinsertion of the agent in society and their preparation to adopt behaviours and guide life in society in a responsible way in the future - it is not all done. Among other aspects, account should be taken of the fact that there are few female prisons, which in many cases leads to a detainee's removal from her area of residence. This circumstantial causes difficulties with regard to visits and, consequently, a total separation from the family, naturally encompassing the children, which do nothing to favour reintegration for later adaptation to life abroad.

The European Parliament Resolution, dated 13 March 2008, on the particular situation of women in prison and the impact of parental detention on social and family life has invited "the Member States to ensure the establishment of prison centers for women and to distribute them better in their territory "and also to resort to "the penalties of substitution of imprisonment, as alternatives based on society especially for mothers, with the exception for the limitations resulting from the penalty they incurred and those imposed in the name public security, since their detention can cause serious disturbances in family life". It also invites the Member States to "apply psycho-social monitoring measures in order to prepare the separation between the child and his imprisoned mother as best as possible and reducing its negative impact" (Official Journal of the European Union, 2009, $\mathrm{ns}^{\mathrm{o}}$ 22, 19 e 29).

If both parents of the minor are serving time in different prisons, visits between the couple and the minor are allowed, when security reasons are not opposed, for family support, preservation of family ties between all and maintenance of the binding relationship, whenever possible, every two weeks (article 250 of the GRPE).

When prisoners have to travel abroad, they may be accompanied by their minor child, whenever the diligence lasting more than one day and having to stay in another prison establishment, provided that he has adequate conditions for that purpose (article 251 of GRPE).

\subsection{The other side of the coin - the victim in the feminine}

If, at times, women, as human beings and therefore also as imperfect beings, let themselves cross the web of an attempt to attack the highest values protected by criminal law, the truth is that official sources reveal to us that they are often the victims of criminal behaviour, especially with regard to the crime of domestic violence.

This numerical reality is the result of a traditional societal experience based on stereotyped gender inequality, reducing the image, position and role of women standardized in the family, at work and generally in society.

One of the objectives - the fifth - of the 2030 Sustainable Development Agenda (composed by 17 objectives and 169 goals to be achieved) consists of achieving gender equality and empowering all women and girls. Portugal has made commitments in terms of public policies within the scope of this Agenda and other international instruments in order to design and put into practice a more just, equitable, developed and sustainable society. To this end, the National Strategy for Equality and Non-Discrimination - "Portugal + Igual" (NSEND) was approved by Resolution of the Council of Ministers no. 61/2018. Of its four lines of action until 2030, we highlight one, about "d) Elimination of all forms of violence against women, gender violence and domestic violence (...)" (Official Journal of Portugal, 2018, no 97), with particular emphasis on the action plan for preventing and combating violence against women and domestic violence (APVWDV). It is intended, essentially, to eliminate any form of social tolerance in the face of externalities of violence, to promote a culture of equality, nondiscrimination and peace and to raise awareness about the harm of violence (Interim Monitoring Report, 2018). 
The Portuguese Association for Victim Support (PAVS), founded since the 1990s, reports in its 2019 Annual Report that it provided 54,403 inquiries corresponding to various forms of crime (against people, against property and other offenses) and violence. It identified an annual average of victims: 8,394 women and 1,617 men, to which 1,350 elderly people and 1,473 children were added (Statistics PAVS, 2019).

Among crimes against people, the crime of domestic violence was the most registered, representing $79 \%$ of the cases, which resulted in 23,586 situations (Statistics PAVS, 2019), values higher than those recorded in 2018 (15,964 /77.5\%) (Statistics PAVS, 2018).

This Association prepared a Report on the statistics of victims of domestic violence between the years 2013 and 2018 and we extracted the following elements from it (Statistics PAVS, November 2019):

1. Gender of the victim: female $(85.82 \%)$ male $(13.72 \%)$;

2. Relationship between the victim and the perpetrator of the crime: $33.3 \%$ spouse;

3. Age group of the most affected victim: between 36 and 45 years old;

4. Marital status of the most affected victim: married;

5. Type of family of the victim most affected: nuclear family with children;

6. Most frequent type of victimization: continued;

7. Average duration of victimization: long - between 2 to 6 years;

8. Dominant civil status of the offender: married

9. Most dominant age group of the perpetrator of the crime: between 36 and 45 years old;

10. Dominant crime scene: common residence.

Statistics from the Directorate-General for Justice Policy, as for the crime of domestic violence, the most recent data are those of the 2018 calendar year. The districts of Lisbon, Porto, Setubal, Aveiro and Braga lead the list of registered crimes, with 5,991 cases in the capital alone.

There is a big difference between the number of people accused $(3,412)$ and the number of convicts $(1,845)$, with $95 \%$ of those convicted being male. Of these convictions, only $10 \%$ corresponded to the term of effective imprisonment, with the institute of suspension of execution of the sentence being frequently applied.

More recently, in 2019, according to the National Statistics Institute, in terms of provisional data, the suspects identified in domestic violence crimes against their spouse or similar, and registered by PSP (Public Security Police) and GNR (Republican National Guard), totalled 26,573, 21,927 males and 4,646 females (Statistics Portugal, 2020).

Despite the fact that we have a legal framework that establishes the legal regime applicable to the prevention of domestic violence, the protection and assistance of its victims, the cases are multiplying with the practice of homicides in between.

The Resolution of the Council of Ministers no. 139/2019, which approves measures to prevent and combat domestic violence, underlined the harmful consequences of this crime beyond the person victimized: it is also the family that supports and suffers, it is the whole community that loses. Pay attention to the numbers: the practice of the crime of homicide in a conjugal or similar context has increased since 2017, from 15 women and 5 men, to 24 women and 13 men in 2 --018 and in 2019, 27 women and 8 men. In the last year, 789 women and 760 minors were taken into residential units for the reception of victims (shelters), and 1193 women taken into emergency care on those shelters, as well as 874 minors (National Strategy for Equality and Non-Discrimination, 2018). 


\section{Final Considerations}

Despite the significant difference between the number of male inmates and female inmates, the Portuguese legislator expressed concern about some relevant aspects, in terms of the fulfilment of private sanctions by women, namely in relation to the state of pregnancy, puerperal, with pre-care. and post-natal, and as for minor children, which is found in the Code of Execution of Sentences and Liberty Deprivation Measures and in the General Regulation of Prison Establishments.

Prisoners may keep their minor children, up to a maximum age of 5, in the prison establishment, with the due authorization of the other parental responsibility holder. The solution should be the one that best protects the minor, being its interest preponderant. It is the responsibility of the prison establishment to create conditions for the existence of spaces and programs that facilitate the inclusive education of these minors and their approximation, as much as possible, with the outside world.

Maternity lived within walls, whether with the minor children present in the prison or with the minor children absent, is one of the greatest difficulties that prisoners face. For this reason, the European Parliament Resolution of 13 March 2008 invited Member States to resort to "the penalties of substitution of imprisonment, as alternatives based on society, especially for mothers (...) since their detention it can cause serious disturbances in family life" and "to apply psycho-social accompanying measures in order to prepare the separation between the son and his imprisoned mother as best as possible and reduce its negative impact".

In this writing, we drew different scenarios, from the reclusive woman victim of her confinement to the woman victim especially of the crime of domestic violence. There are several official sources that provide us with figures indicating this reality. They are the main victims in quantitative terms and homicides committed in conjugal or similar contexts are increasing, with all the harmful consequences at the family and social level. In 2019, 789 women and 760 minors were housed in shelters in 2019 and 1193 women and 874 minors were in emergency mode.

The fifth objective of the 2030 Sustainable Development Agenda aims to achieve gender equality and empower all women and girls. In this context Portugal approved the National Strategy for Equality and Non-Discrimination - "Portugal + Igual" (NSEND) in the Resolution of the Council of Ministers no. 61/2018 which aims to eradicate, among other forms of violence, domestic violence.

Finishing we would like to point out some suggestions for future researches and work. As we have seen, when it comes to the application of measures depriving women of their liberty, their specific needs and those of their children, if any, must be taken into consideration. We are aware that we are still far from reaching the level of protection necessary for the integral defence of their rights. We strongly recommend further study of these matters in future research, with a view to drawing attention to the need for the State to adopt measures to ensure women's rights during the enforcement of sentences, taking into account the particular circumstances of their condition, and to create mechanisms to protect them preventively as victims of crime.

\section{References}

Ary, D., Jacobs, L., Sorensen, C., \& Walker, D. (2014). Introduction to research in education, (9a ed.), Cengage Learning.

Beleza, T. P. (2004). Anjos e monstros - a construção das relações de género no Direito Penal. Ex aequo (10), 29-40.

Canotilho, J. J. G. \& Moreira V. (2007). Constituição da República Portuguesa Anotada, I. Coimbra Editora.

Cunha, M. I. (2007). A prisão segundo o género: Os estudos prisionais, a reclusão de mulheres e a variação dos contextos da identidade. Educar o Outro - As Questões de Género, dos Direitos Humanos e da Educação nas Prisões Portuguesas. Editor Humana Global, 81-87.

Directorate-General for Justice Policy/Direção-Geral da Política de Justiça (2020) - Estatísticas da Justiça. https://estatisticas.justica.gov.pt/sites/siej/ptpt/paginas/default.aspx. 
Research, Society and Development, v. 10, n. 16, e179101622422, 2021

(CC BY 4.0) | ISSN 2525-3409 | DOI: http://dx.doi.org/10.33448/rsd-v10i16.22422

Directorate-General for Justice Policy. Domestic violence (2018) /Direção-Geral da Política de Justiça (2020) - Violência doméstica. https://estatisticas.justica.gov.pt/sites/siej/pt-pt/Paginas/Violencia_domestica.aspx.

Directorate-General of Reintegration and Prison Services/Statistics and Indicators/Prisons / Direção-Geral de Reinserção e Serviços Prisionais/Estatísticas e Indicadores/Prisionais (2019). https://dgrsp.justica.gov.pt/Estat\%C3\%ADsticas-e-indicadores/Prisionais/2019.

Estrela, C. (2018). Metodologia Científica: Ciência, Ensino, Pesquisa. Editora Artes Médicas.

Guimarães, A. R. S. (2015). Reclusão Feminina: Maternidade e Nacionalidade [dissertação de Mestrado em Psicologia não publicada]. Universidade Católica Portuguesa.

Interim Monitoring Report (2018). Commission for Citizenship and Gender Equality /Relatório Intercalar de Monitorização da Comissão para a Cidadania e a Igualdade de Género (2018). https://www.cig.gov.pt/wp-content/uploads/2019/04/ENIND-Relat\%C3\%B3rio-2018.pdf.

Leitch, R. \& Day, C. (2000). Action research and reflective practice: towards a holistic view. Educational Action Research, 8 (1), 179-193, $10.1080 / 09650790000200108$.

Lemos, A. (2012). Ensino, Aprendizagem e Avaliação no Ensino Superior: Perspetivas dos Estudantes Mestrado em Ciências da Educação - Área de Especialização em Desenvolvimento Curricular Universidade do Minho.

Matos, R. N. C. (2006). Vidas raras de mulheres comuns. Percursos de vida, significações do crime e construção da identidade em jovens reclusas [Tese de Doutoramento de Psicologia não publicada]. Universidade do Minho.

National Strategy for Equality and Non-Discrimination - "Portugal + Igual" (NSEND)/ Estratégia Nacional para a Igualdade e a Não Discriminação - Portugal

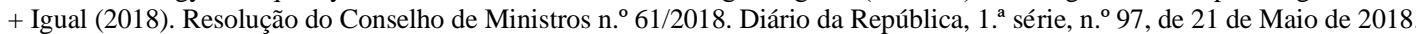

Official Journal of the European Union/Jornal Oficial da União Europeia (2009). C 66 E/54, of 20/03/2009.

Official Journal of Portugal/ Diário da República, (97), de 21 May 2018.

Ombudsman's Office/ Provedoria de Justiça (2003). As $\quad$ Nossas $\quad$ Prisões, $126 . \quad$ https://www.provedorjus.pt/site/public/archive/doc/AsNossas_Prisoes_IIIRelatorio.pdf.

Pereira, A. S.; Shitsuka, D. M.; Parreira, F. J. \& Shitsuka, R. (2018). Metodologia da pesquisa científica. UFSM. https://www.ufsm.br/app/upload s/sites/358/2019/02/Metodologia-da-Pesquisa-Cientifica_final.pdf.

Pordata (2020). Base de Dados Portugal Contemporâneo - Portugal - Justiça e Segurança - Prisões - Reclusos: total e por sexo. https://www.pordata.pt/Portugal/Reclusos+total+e+por+sexo-271.

Relatório Anual de Segurança Interna (2019). Sistema de Segurança Interna. https://www.portugal.gov.pt/download-ficheiros/ficheiro.aspx?v=19cabc8c-e3f14cb2-a491-a10c8a3e4bf0.

Statistics PAVS (2018) /Estatísticas APAV (2018). Relatório Anual, https://apav.pt/apav_v3/images/pdf/Estatisticas_APAV_Relatorio_Anual_2018.pdf

Statistics PAVS (2019) Estatísticas APAV. Violência Doméstica 2013-2018. https://apav.pt/apav_v3/images/pdf/ Estatisticas_APAV_Violencia_Domestica_2013_2018.pdf.

Statistics PAVS (2019) /Estatísticas APAV (2019). Relatório Anual. https://apav.pt/apav_v3/images/pdf/Estatisticas_APAV-Relatorio_Anual_2019.pdf

Statistics Portugal (2020) / Portal do INE, Instituto Nacional de Estatística. https://www.ine.pt/xportal/xmain?xpid=INE\&xp gid=ine_indicadores\&indOcorrCod=0008154\&contexto=pgi\&selTab=tab10.

Torres, A. C. \& Gomes, M. (2005). Drogas e Prisões: relações próximas. Revista Toxicodependências, Edição IDT, 11, (2), 23-40.

Torres, A. C. \& Gomes, M. (2002). Drogas e Prisões em Portugal.CIES/ISCTE. 